\title{
Identification of transcriptional targets associated with the expression of $\mathrm{p} 210$ $\mathrm{Bcr}-\mathrm{Abl}$
}

Hickey FB, Cotter TG. Identification of transcriptional targets associated with the expression of p210 Bcr-Abl.

Abstract: Objectives: Chronic myeloid leukaemia is caused by the expression of the p210 Bcr-Abl fusion protein which results from the Philadelphia translocation, $t(9 ; 22)$. This oncogene has been the focus of extensive research. However, the molecular mechanisms responsible for the haematological malignancy are not fully understood. The main objective of the current study was to identify novel transcriptional targets of Bcr-Abl. Methods: In order to achieve this, microarrays were employed in order to conduct a genome-wide expression analysis comparing 32D cells with a transfected clone expressing high levels of p210 Bcr-Abl. Quantitative RT-PCR was employed in order to confirm the observed increase/decrease in expression for a number of the deregulated genes. Results and conclusions: This comparison identified 138 genes of known function showing altered expression in response to Bcr-Ablmediated signalling. Among the genes found to be upregulated in response to p210 Bcr-Abl were aldolase 1A and phosphofructokinase, both of which encode key enzymes in the glycolytic pathway. As a consequence of this, we demonstrate that the rate of glycolysis is significantly increased in Bcr-Abl expressing cells in a PI3K-dependent manner. Our results also indicate altered expression of genes involved in cell proliferation, cell adhesion and cell signalling.

\author{
Fionnuala B. Hickey, Thomas G. \\ Cotter
}

Department of Biochemistry, Biosciences Institute, University College Cork, Cork, Ireland

Key words: Bcr-Abl; chronic myeloid leukaemia; Philadelphia chromosome; microarray analysis; gene expression profiling; glycolysis; proliferation; PI3K

Correspondence: Prof. T. G. Cotter, Department of Biochemistry, Biosciences Institute, University College Cork, Cork, Ireland

Tel: +353-21-4901321

Fax: +353-21-4901382

e-mail: t.cotter@ucc.ie

Accepted for publication 12 December 2005
The Philadelphia chromosome results from the $\mathrm{t}(9 ; 22)(\mathrm{q} 34 ; \mathrm{q} 11)$ translocation which fuses the $B c r$ and $c-A b l$ genes (1). Three different forms of the Bcr-Abl fusion protein occur, p185, p210 and p230 depending on the breakpoint in the $\mathrm{Bcr}$ gene (2). All forms of Bcr-Abl result in leukaemia, however, the cell type affected and the course of the disease differ for each form. p210 Bcr-Abl is seen in $95 \%$ of patients with chronic myeloid leukaemia (CML) and is generally believed to be the causative agent. The other two forms of Bcr-Abl occur less frequently. p185 Bcr-Abl is seen in approximately $25 \%$ of patients with acute lymphocytic leukaemia (ALL) while the p230 form has been associated with a subset of chronic neutrophilic leukaemia (CNL) patients. All versions of Bcr-Abl display enhanced tyrosine kinase activity compared with the normal Abl kinase, and this is crucial for transformation.
Chronic myeloid leukaemia is a myeloproliferative disorder which results in the primitive release of immature myeloid cells into the blood (3). Cellular characteristics of CML include growth factor independence (4), adhesion independence (5), and resistance to drug-induced apoptosis (6). This drug-resistance makes CML very difficult to manage clinically. Although a number of signal transduction pathways have been shown to be activated by Bcr-Abl, the exact mechanisms leading to transformation are still largely unknown. Among the pathways implicated are the Ras (7), PI3K (8) and JAK (Janus kinase)/STAT (signal transducer and activator of transcription) pathways (9). STATs represent a family of five proteins, when phosphorylated they become activated and subsequently dimerise and translocate to the nucleus where they activate transcription (10). To date these are the only transcription factors known to be 
regulated by tyrosine phosphorylation and as such present a potential direct target of Bcr-Abl. Bcr-Abl has been shown to mainly phosphorylate STAT5 leading to it's constitutive activation (11). However, there have also been some reports of STAT1 and STAT3 activation by Bcr-Abl, although to a lesser extent (12).

It has been reported that the resistance of CML cells to drug-induced apoptosis is mainly dependent on the Ras and PI3K pathways $(13,14)$. However, a better understanding of this acquired drug resistance would inevitably lead to better treatment options for patients. In order to achieve this it is necessary to unravel the underlying molecular mechanisms of transformation by Bcr-Abl. Currently very little is known about the downstream effects of Bcr-Abl on transcription. It is hoped that the identification of genes differentially expressed in response to p210 Bcr-Abl will allow a better understanding of the molecular mechanisms of CML, possibly identifying new targets for therapy. One of the technologies enabling this is transcriptional profiling (15).

We applied microarray technology to a normal mouse haematopoietic cell line (32D) and a transfected clone of this cell line expressing high levels of p210 Bcr-Abl (C4). In this report we detail the findings of this microarray experiment and also describe the confirmation of altered expression of chosen genes of interest by real-time RT-PCR in both $\mathrm{C} 4$ cells and a human CML cell line - K562. Among the genes found to be upregulated in response to Bcr-Abl expression were several with reported involvement in cellular adhesion including gamma parvin and cadherin 5. We also found that a number of genes encoding glycolytic enzymes were upregulated and we demonstrate that this results in a significantly increased rate of glycolysis in these cells. We also present evidence that this increased glycolytic activity is dependent on the PI3K pathway. We found that while Bcr-Abl affects the expression levels of many genes involved in cellular proliferation and cell cycle progression, including Fyn, cyclin G2 and cyclin D3, no overall affect was seen on the rate of growth of Bcr-Ablpositive cells in comparison with the parental cell line under normal culture conditions. However, the increased expression of these genes may be involved in the IL-3-independent proliferation of C4 cells.

\section{Materials and methods}

Cell culture, transfection and reagents

The 32D cell line was maintained in RPMI 1640 (Gibco Invitrogen Corporation, Paisley, UK) with $10 \%$ WEHI conditioned media (WE-HI CM) as a source of IL-3. The Bcr-Abl expressing C4 clone was maintained in RPMI 1640, containing $0.2 \mu \mathrm{g} /$ $\mathrm{mL}$ puromycin (Sigma-Aldrich, Dublin, Ireland). C4 cells treated with STI571 were cultured in the presence of $10 \%$ WE-HI CM. C4 cells transfected with dnp110 $\gamma(\mathrm{K} 832 \mathrm{R})$ were maintained in media supplemented with $250 \mu \mathrm{g} / \mathrm{mL}$ G418 sulphate (geneticin; Sigma-Aldrich). K562 cells were cultured in RPMI 1640 containing $200 \mu \mathrm{M}$ L-glutamine (Sigma-Aldrich). Recombinant human granulocyte-macrophage colony-stimulating factor (rhGMCSF; Sigma-Aldrich) was added to the media of K562 cells treated with STI571, at a final concentration of $20 \mathrm{ng} / \mathrm{mL}$. All cultures were supplemented with $10 \%$ foetal calf serum, $100 \mathrm{U} / \mathrm{mL}$ penicillin and $1 \mathrm{mg} / \mathrm{mL}$ streptomycin (Sigma-Aldrich). The pcDNA3 vector encoding dominant negative $\mathrm{p} 110 \gamma(\mathrm{K} 832 \mathrm{R})$ was kindly provided by Dr R. Wetzker (University of Jena, Germany). Transfection of C4 cells was achieved by electroporation using a Gene Pulser apparatus (Bio-Rad, Alpha Technologies, Dublin, Ireland). Stably transfected clones were obtained by serial dilution in media containing $700 \mu \mathrm{g} / \mathrm{mL}$ G418. STI571 was kindly provided by Novartis (Basel, Switzerland); LY294002 was purchased from Calbiochem (Merck Biosciences, Nottingham, UK).

\section{Cell lysis and immunoblotting}

Cells were lysed in RIPA buffer [ $50 \mathrm{~mm}$ Tris- $\mathrm{HCl}$ (pH 7.4), 1\% NP-40, 0.25\% sodium deoxycholate, $150 \mathrm{~mm} \mathrm{NaCl}, 1 \mathrm{~mm}$ EGTA, $1 \mathrm{~mm} \mathrm{Na} \mathrm{VO}_{4}, 1 \mathrm{~mm}$ $\mathrm{NaF}, 1 \mu \mathrm{g} / \mathrm{mL}$ antipain, $1 \mu \mathrm{g} / \mathrm{mL}$ aprotinin, $1 \mu \mathrm{g} /$ $\mathrm{mL}$ chymostatin, $0.1 \mu \mathrm{g} / \mathrm{mL}$ leupeptin, $1 \mu \mathrm{g} / \mathrm{mL}$ pepstatin and $100 \mu \mathrm{M}$ PMSF]. The lysates were centrifuged at $20000 \mathrm{~g}\left(4^{\circ} \mathrm{C}\right)$ for $15 \mathrm{~min}$ to remove insoluble debris. Equivalent amounts of protein, as determined by the Bio-Rad Protein Assay, were resolved using SDS-PAGE and transferred to nitrocellulose membrane (Schleicher and Schuell, Dassel, Germany). All secondary antibodies were peroxidase conjugated and proteins were detected using Enhanced Chemiluminescence (Amersham Biosciences, Little Chalfont, UK). Antibodies: anti-c-Abl (AB-3) (Calbiochem), anti-phosphotyrosine (PY20) (Transduction Laboratories, San Diego, CA, USA), anti-phospho-AKT (ser 473) and anti-AKT (Cell Signaling Technology, Danvers, MA, USA), anti- $\beta$-actin (Sigma-Aldrich).

\section{Measurement of apoptosis (phosphatidyl serine exposure)}

The exposure of phosphatidyl serine (PS) on the extracellular surface of the plasma membrane was monitored by the binding of annexin V-fluorescein isothiocyanate (FITC), according to the 
manufacturer's instructions (IQ Products; Labron Ltd, Dublin, Ireland). Briefly, $5 \times 10^{5} / \mathrm{mL}$ cells were resuspended in calcium binding buffer $(10 \mathrm{~mm}$ HEPES, $2.5 \mathrm{~mm} \mathrm{CaCl}_{2}, 140 \mathrm{~mm} \mathrm{NaCl}$ ) and incubated with annexin V-FITC for $5 \mathrm{~min}$ at room temperature in the dark. Cells were incubated with $50 \mu \mathrm{g} / \mathrm{mL}$ propidium iodide (PI) at room temperature before analysis. Fluorescence resulting from FITC and PI was measured at $530 \mathrm{~nm}$ (FL1) and $590 \mathrm{~nm}$ (FL2), respectively, and analysed using CELLQUEST software on a FACScan flow cytometer (Becton Dickinson, Oxford, UK) using an excitation of $488 \mathrm{~nm}$.

\section{Microarray hybridisation procedure}

Total cellular RNA was prepared using Tri Reagent (Biosciences, Dublin, Ireland). Probe synthesis was carried out as described in the GeneFilters Microarray protocol (Research Genetics, Invitrogen, Biosciences, Dublin, Ireland). Briefly, cDNA was synthesised from $10 \mu \mathrm{g}$ total RNA using oligodT primer with $\left[\alpha-{ }^{33} \mathrm{P}\right]$-labelled dCTP (Amersham Biosciences, Freiburg, Germany). cDNA probes were purified by passage through a Bio-Spin 6 chromatography column (Bio-Rad, Hemel Hempstead, UK). ResGen GeneFilters (Invitrogen) were prehybridised with $5 \mu \mathrm{g}$ denatured Cot-1 DNA prior to addition of labelled probe. Hybridisation was allowed to proceed for $18 \mathrm{~h}$ at $42^{\circ} \mathrm{C}$. Two washes were performed at $50^{\circ} \mathrm{C}$ with $2 \mathrm{X} \mathrm{SSC} ; 1 \%$ SDS for $20 \mathrm{~min}$ and one wash at $55^{\circ} \mathrm{C}$ with $0.5 \mathrm{X}$ SSC; $1 \%$ SDS for 20 min. Imaging of microarray membranes was achieved using a STORM 860 phosphorimager (Amersham Biosciences). Microarray experiments were carried out once.

Microarray data interpretation

Arrays were analysed using ARRAY VISION software (Imaging Research Inc., ON, Canada). The intensity of all spots was adjusted by subtracting the local background from the observed intensity (sDensity). Intensity data were normalised for both arrays by means of the widely used global intensity normalisation method (16). Average global background for each array was then calculated, and at this point all spots for which the adjusted intensity was less than 2 standard deviations above average background were flagged and omitted from subsequent analysis (17). For each remaining spot the ratio of the adjusted intensity in array 1 to that in array 2 was calculated. A greater than twofold difference in expression levels was considered to be significant. Identities of expressed sequence tags (ESTs) were determined primarily by use of the FatiGO web tool (http:/fatigo.bioinfo.cnio.es), this program also categorised identified genes based on their function using Gene Ontology (GO) terms (18).

\section{Real-time RT-PCR}

Total cellular RNA was prepared using Tri Reagent (Biosciences, Dublin, Ireland). Single-stranded cDNA was synthesised according to the M-MLV Reverse Transcriptase protocol (Promega, Southampton, UK). Oligo dT, $\mathrm{MgCl}_{2}$ and RNAsin were also purchased from Promega. dNTPs were obtained from Sigma-Aldrich. Real-time PCR was performed using DyNAmoSYBR Green qPCR kit (Finnzymes, Essex, UK) on an Opticon 2 DNA Engine (MJ Research, Essex, UK) according to the manufacturer's instructions. PCR reactions were carried out as follows: $95^{\circ} \mathrm{C}$ for $5 \mathrm{~min} ; 35$ cycles of $-95^{\circ} \mathrm{C}$ for $1 \mathrm{~min}, T_{\text {anneal }}$ for $1 \mathrm{~min}, 72^{\circ} \mathrm{C}$ for $1 \mathrm{~min}$ - followed by $72^{\circ} \mathrm{C}$ for $5 \mathrm{~min}$. Sequences of primers used for all genes are listed in Table 1, along with annealing temperatures and product sizes. All primers were purchased from MWG Biotech (Milton Keynes, UK). In all cases, three biological replicates were used to confirm altered expression

Table 1. Primers used for real-time RT-PCR. For each gene studied by real-time RTPCR forward and reverse primers are listed, along with the annealing temperature used and the size of the PCR product obtained

\begin{tabular}{|c|c|c|c|}
\hline Gene & Primers & $\begin{array}{c}T_{\text {anneal }} \\
\left({ }^{\circ} \mathrm{C}\right)\end{array}$ & $\begin{array}{l}\text { Product } \\
\text { (bp) }\end{array}$ \\
\hline \multicolumn{4}{|l|}{ Mouse } \\
\hline Gamma Parvin & $\begin{array}{l}\text { For: 5'-GCCTGTTCAGCTACCCTGTC-3' } \\
\text { Rev: 5'-GACTGCTGGGTCCTTCAGAG-3' }\end{array}$ & 55 & 199 \\
\hline Calmodulin 1 & $\begin{array}{l}\text { For: 5'-GAGAATGGGGGAAGGCTAAA-3' } \\
\text { Rev: 5'-GCAATGTTGATGGTGTGCTC-3' }\end{array}$ & 55 & 300 \\
\hline Mina & $\begin{array}{l}\text { For: 5'-AGCCCACAGGGGATGAGAACGA-3' } \\
\text { Rev: 5'-AATGTGGAGGGAGGCCCTGAGA-3' }\end{array}$ & 63 & 522 \\
\hline COX VIIla & $\begin{array}{l}\text { For: 5'-TTCCTGCTTCGTGTGTTGTC-3' } \\
\text { Rev: 5'-TGCAGAGGTGACTGGAA-3' }\end{array}$ & 55 & 201 \\
\hline Aldolase $1 \mathrm{~A}$ & $\begin{array}{l}\text { For: 5'-ATGGGCCTTGACTTTCTCCT-3' } \\
\text { Rev: 5'-GTGATGGGAAAGAGCCTGAA-3' }\end{array}$ & 55 & 303 \\
\hline Phosphofructokinase & $\begin{array}{l}\text { For: 5'-TCACCATCCTTGGGCATGTCCA-3' } \\
\text { Rev: 5'-TGGACCCTCCTTGTCCAGTCCA-3' }\end{array}$ & 63 & 522 \\
\hline PI3Kgamma & $\begin{array}{l}\text { For: 5'-GCTCTTGGCAGAAAAAGGTG-3' } \\
\text { Rev: 5'-CCTGGGCATCTCAGTGGTAT-3' }\end{array}$ & 55 & 169 \\
\hline \multicolumn{4}{|c|}{ 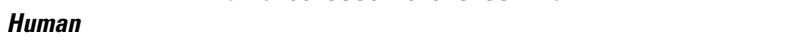 } \\
\hline Gamma Parvin & $\begin{array}{l}\text { For: 5'-CTCAGCTGCCCTGTCAGCCCTGA-3' } \\
\text { Rev: 5'-GCCAGGCGGCTCAAAATGATCCACA-3' }\end{array}$ & 69 & 299 \\
\hline Calmodulin 1 & $\begin{array}{l}\text { For: 5'-CTCAAGTCTTTAGAAGCTGGGTGGA-3' } \\
\text { Rev: } 5^{\prime} \text {-AGGACATTTGAGAACGGGGATGAAG-3' }\end{array}$ & 64 & 300 \\
\hline Mina & $\begin{array}{l}\text { For: 5'-GCAGAAGCCCCTTCTCATTCAGAGA-3' } \\
\text { Rev: 5'-AGGAACCAACCGAGCTTACACATGT-3' }\end{array}$ & 66 & 298 \\
\hline COX VIIla & $\begin{array}{l}\text { For: 5'-CCAGCGGGCTGGATCCTGTCACA-3' } \\
\text { Rev: 5'-ACCACTGGAGGAACCCCCAGTGAC-3' }\end{array}$ & 69 & 199 \\
\hline Aldolase $1 \mathrm{~A}$ & $\begin{array}{l}\text { For: 5'-CTTCTACCGCCAGCTGCTGCTGA-3' } \\
\text { Rev: 5'-ACCTTCCGTGGAACGACTTCGGG-3' }\end{array}$ & 68 & 500 \\
\hline Phosphofructokinase & $\begin{array}{l}\text { For: } 5^{\prime} \text {-GAAGGCTGGGAGGAGCA-3' } \\
\text { Rev: 5'-GTGGTTCCCGTTCAGTGA-3' }\end{array}$ & 56 & 300 \\
\hline PI3Kgamma & $\begin{array}{l}\text { For: 5'-CACTTAACCCTCTCACAGCAGAGGA-3' } \\
\text { Rev: 5'-ACCAGGTCCGACACTTTAAACTTGG-3' }\end{array}$ & 65 & 300 \\
\hline
\end{tabular}


(i.e. three separate RNA extractions were performed). To control for DNA contamination of RNA samples, PCR was also carried out in the absence of reverse transcription. In this case MMLV was omitted from the reverse transcription reaction.

\section{Assessment of cell viability}

Cell viability was assessed by PI exclusion on a FACScan (Becton Dickinson) flow cytometer at $590 \mathrm{~nm}$ (FL-2). Cells were incubated with $50 \mu \mathrm{g} /$ $\mathrm{mL}$ PI at room temperature prior to analysis. The criteria for cell death as measured by flow cytometry were based on changes in light scattering properties of dead cells due to cell shrinkage and increased granularity and also permeability to PI.

\section{Cell proliferation assay}

Cells were plated at a density of $0.1 \times 10^{6}$ cells $/ \mathrm{mL}$. Cell numbers from aliquots of time course experiments were determined by trypan blue exclusion assay using a Neubauer haemocytometer.

\section{Glycolysis assay}

32D and C4 cells and $\mathrm{C} 4$ cells pretreated for $48 \mathrm{~h}$ with $1 \mu \mathrm{M}$ STI571 $\left(0.5 \times 10^{6}\right.$ cells each $)$ were incubated in $0.5 \mathrm{~mL}$ Krebs bicarbonate buffer $\left(2.5 \mathrm{~mm} \mathrm{CaCl}, 1.2 \mathrm{~mm} \mathrm{MgSO}_{4}, 4.7 \mathrm{~mm} \mathrm{KCl}\right.$, $1.2 \mathrm{~mm} \mathrm{KH}_{2} \mathrm{PO}_{4}, 0.1 \mathrm{M} \mathrm{NaCl}, 25 \mathrm{~mm} \mathrm{NaHCO}$, $11 \mathrm{~mm}$ glucose) with $20 \mu \mathrm{Ci} / \mathrm{mL}$ of $5-{ }^{3} \mathrm{H}$ glucose (Amersham Biosciences) for $2 \mathrm{~h}$ at $37^{\circ} \mathrm{C}$ in microassay tubes within sealed scintillation vials. Cells were killed by the addition of $0.5 \mathrm{~mL} 0.2 \mathrm{M} \mathrm{HCl}$. Glucose utilisation was assayed according to Ashcroft et al. (19). Briefly, ${ }^{3} \mathrm{H}_{2} \mathrm{O}$ production was calculated by counting on a Beckman Coulter LS 6500 scintillation counter (High Wycombe, UK). Appropriate positive and negative controls (without cells) were also performed alongside.

\section{Results}

Characterisation of cell line model of $\mathrm{CML}$

The Philadelphia chromosome, caused by the reciprocal translocation $\mathrm{t}(9 ; 22)(\mathrm{q} 34 ; \mathrm{q} 11)$, results in the expression of the $B c r-A b l$ oncogene. This was the first consistent chromosomal abnormality to be identified in a cancer (20), with the $210 \mathrm{kDa}$ form of Bcr-Abl being detected in $95 \%$ of all CML cases. Since the identification of Bcr-Abl as the causative oncogene of CML, many downstream pathways and targets have been identified. However, very little is known about the affect of Bcr-Abl on gene expression. Therefore, in order to identify genes regulated by $\mathrm{Bcr}-\mathrm{Abl}$ we employed microarray analysis to compare 32D and $\mathrm{C} 4$ cell lines. 32D cells are IL-3-dependent myeloid progenitor cells, while $\mathrm{C} 4$ cells are a stably transfected clone of 32D cells expressing high levels of p210 Bcr-Abl (Fig. 1A). The $A b l$ gene encodes a non-receptor tyrosine kinase which, when fused to $B c r$, becomes constitutively active. As such phosphotyrosine levels can be used as a measure of Bcr-Abl activity in cells. Figure 1B shows that $\mathrm{C} 4$ cells display greatly increased levels of phosphotyrosine

A $32 \mathrm{D} \quad \mathrm{C} 4$

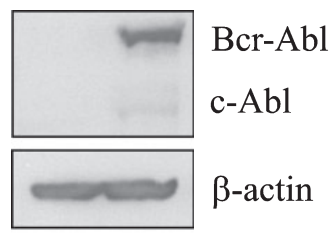

$\mathbf{B}$
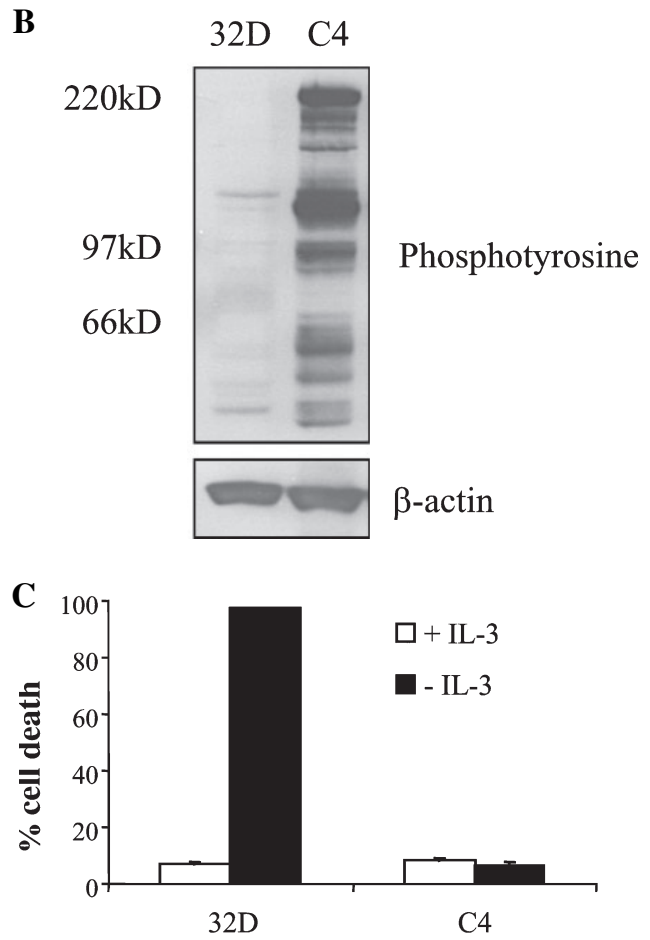

Fig. 1. Characterisation of $32 \mathrm{D}$ and $\mathrm{C} 4$ cell lines. (A) Western blot analysis of Bcr-Abl expression in total cell lysates from parental 32D cells and Bcr-Abl-transfected C4 cells. (B) Western blot analysis of phosphotyrosine levels in 32D and C4 cells as determined by PY20 antibody binding. The molecular weights of protein markers are indicated. In (A) and (B) actin antibody binding demonstrates equal protein loading. (C) $32 \mathrm{D}$ and $\mathrm{C} 4$ cells were cultured in the presence or absence of IL-3 for $48 \mathrm{~h}$ and assessed for cell death by PI uptake and flow cytometry. Data are presented as the mean and standard error of the mean for independent experiments $(n=3)$. 
compared with the parental 32D cell line, indicating a high level of Bcr-Abl tyrosine kinase activity in these cells. A further characteristic of CML is growth factor-independent growth. As shown in Fig. 1C, transfection of 32D cells with Bcr-Abl results in IL-3 independent growth, as would be expected. We demonstrate that when IL-3 is withdrawn from the media of $32 \mathrm{D}$ cells, $100 \%$ death is observed after $48 \mathrm{~h}$, while $\mathrm{C} 4$ cells can be cultured indefinitely in the absence of IL-3.
Bcr-Abl-specific inhibitor STI571 reverts the phenotype of C4 cells to that of $32 \mathrm{D}$ cells

STI571 (Gleevec) is a specific inhibitor of Bcr-Abl tyrosine kinase activity (21). When $\mathrm{C} 4$ cells are treated with this pharmacological inhibitor the phenotype is reverted to that of $32 \mathrm{D}$ cells. This is demonstrated by a reduction in phosphotyrosine levels in a dose-dependent manner (Fig. 2A). As shown, treatment of $\mathrm{C} 4$ cells with $1 \mu \mathrm{M}$ STI571

A

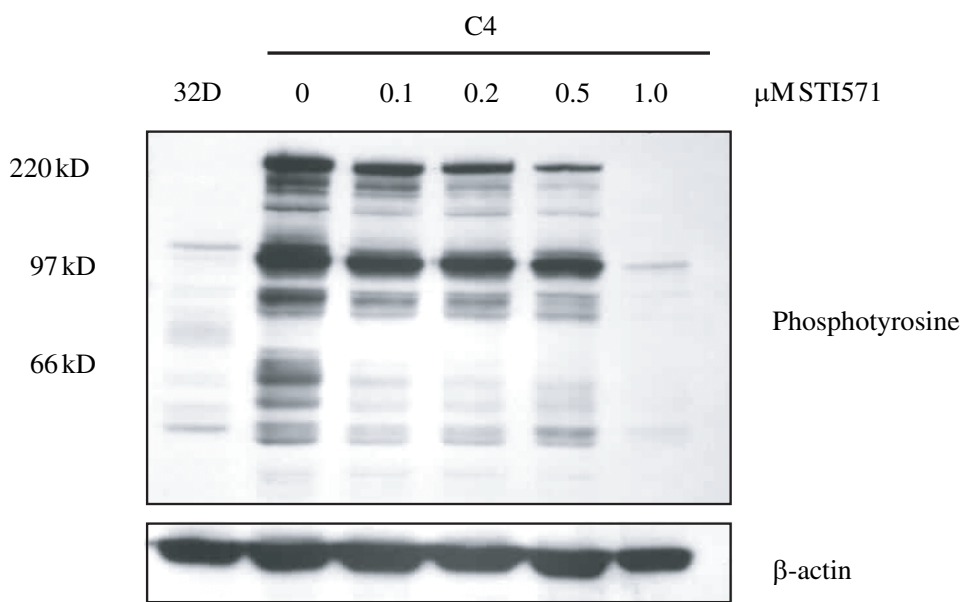

B
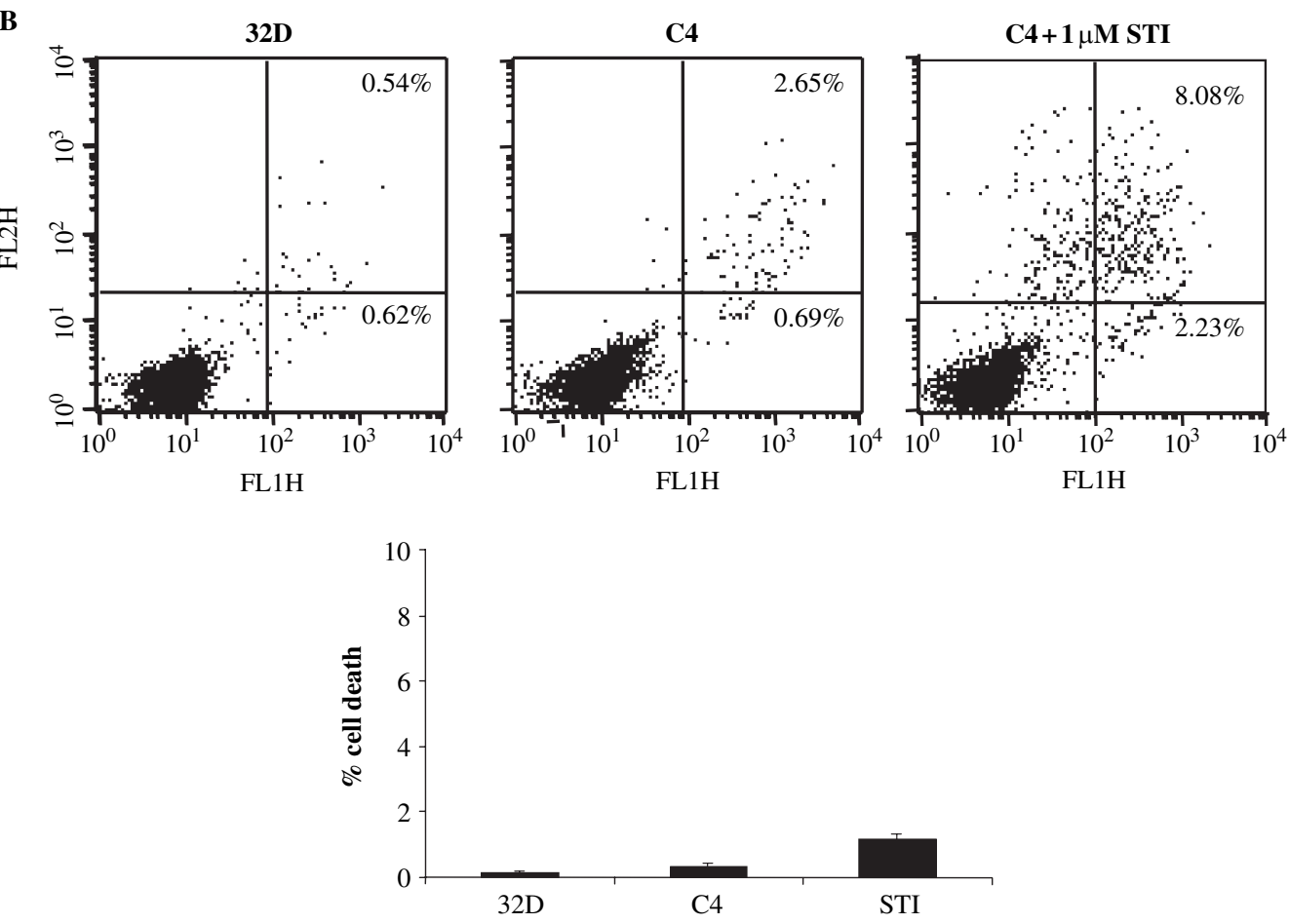

Fig. 2. Bcr-Abl-specific inhibitor STI571 reverts phenotype of C4 cells to that of 32D cells. (A) Western blot analysis of phosphotyrosine levels in total cell lysates from 32D, untreated C4 cells and C4 cells treated with $0.1-1 \mu \mathrm{M}$ STI571 for $48 \mathrm{~h}$. Actin antibody binding demonstrates equal protein loading. (B) Upper panel: Untreated 32D and C4 cells and C4 cells treated for $48 \mathrm{~h}$ with $1 \mu \mathrm{M}$ STI571 (STI) were assessed for apoptotic cell death by annexin V/PI staining. Percentages in bottom right quadrant indicate annexin V positive, PI negative cells, and percentages in top right quadrant indicate annexin V positive, PI positive cells. Data are representative of three independent experiments. Lower panel: Data from upper panel are presented graphically as the mean and standard error of the mean for independent experiments $(n=3)$. 
for $48 \mathrm{~h}$ results in a reduction in phosphotyrosine levels equivalent to those seen in the parental 32D cell line. This confirms that, with this treatment, Bcr-Abl tyrosine kinase activity has been completely abolished in the $\mathrm{C} 4$ cell line. The inhibition of Bcr-Abl activity is further evident from the fact that $\mathrm{C} 4$ cells treated with $1 \mu \mathrm{M}$ STI571 for $48 \mathrm{~h}$ become dependent on IL-3 for survival, similar to $32 \mathrm{D}$ cells. In the absence of IL-3, treatment with STI571 results in $100 \%$ death, however, this death can be prevented by adding We-Hi conditioned media as a source of IL-3 to the culture medium of C4 cells during the treatment (data not shown). Thus, treatment with STI571 allows us to block the activity of Bcr-Abl in $\mathrm{C} 4$ cells, thereby allowing us to ensure that any differences seen between the parental and transfected cell lines are in fact due to the tyrosine kinase activity of Bcr-Abl. Also, as seen in Fig. 2B, treatment with STI571 in the presence of IL-3 does not result in significant cytotoxicity, as demonstrated by annexin V/PI staining. This allows us to confirm that any affects seen after treatment are due to the inhibition of Bcr-Abl, and not as a result of cell death.

\section{Differential expression of genes in Bcr-Abl expressing cells}

In order to compare gene expression profiles between 32D and $\mathrm{C} 4$ cells, and to identify genes differentially expressed in response to Bcr-Abl, mRNA prepared from both of these cell lines was subjected to microarray analysis. The arrays used, ResGen GeneFilters, represented 5184 cDNAs (including both known genes and ESTs). Arrays were analysed using ARRAY VISION software as described in the Materials and methods section. For this study we considered a change factor of 2 to be significant. This threshold value was chosen as a large proportion of the deregulated genes showed change factors between 2 and 3 . It is also of interest to note that in the $\mathrm{Bcr}-\mathrm{Abl}$ positive $\mathrm{C} 4$ cells a greater proportion of genes were found to have increased rather than decreased expression. The majority of cDNAs found to have increased or decreased expression in $\mathrm{C} 4$ cells represented ESTs. Where possible the identities of these ESTs were determined through the web-based FatiGO program (18). This tool was also used in order to categorise genes with altered expression based on their function. This is achieved using GO terms. It was found that genes involved in a great number of cellular processes showed differential expression between $32 \mathrm{D}$ and $\mathrm{C} 4$ cells. These processes include cell adhesion, cell proliferation, protein biosynthesis, transcription, carbohydrate metabolism, etc. Genes with altered expression
Table 2. Genes differentially expressed in C4 cells compared with 32D cells. Genes are categorised based on function. Within each functional category genes are listed in order of change factor, i.e. from highest increase in expression to lowest decrease. All change factors refer to expression in C4 cells compared with that of $32 \mathrm{D}$ cells

\begin{tabular}{|c|c|c|}
\hline Accession number & Change factor & Description \\
\hline \multicolumn{3}{|l|}{ Cell adhesion } \\
\hline Al465485 & 3.43 & Parvin, gamma \\
\hline Al465458 & 2.72 & C-type lectin-like receptor 2 \\
\hline Al413120 & 2.64 & Cadherin 5 \\
\hline Al426143 & -2.47 & Breast cancer anti-oestrogen resistance 1 \\
\hline \multicolumn{3}{|l|}{ Cell proliferation } \\
\hline Al449204 & 4.03 & Myc-induced nuclear antigen \\
\hline Al327027 & 3.31 & Calmodulin 1 \\
\hline Al448320 & 3.05 & Fyn proto-oncogene \\
\hline Al451693 & 2.76 & Centromere protein $\mathrm{E}$ \\
\hline Al451894 & 2.51 & Cyclin G2 \\
\hline Al894223 & 2.47 & Mitogen-activated protein kinase 13 \\
\hline Al451502 & 2.33 & Retroviral integration site 2 \\
\hline Al452358 & 2.28 & $\begin{array}{l}\text { Cell division cycle } 27 \text { homolog } \\
\text { (Saccharomyces cerevisiae) }\end{array}$ \\
\hline Al448557 & 2.26 & $\begin{array}{l}\text { RNA binding motif, single-stranded } \\
\text { interacting protein } 1\end{array}$ \\
\hline Al323871 & 2.24 & Cyclin D3 \\
\hline Al447777 & 2.13 & MutS homolog 6 (Escherichia colı) \\
\hline Al464342 & 2.12 & Calmegin \\
\hline Al449492 & -2.03 & $\begin{array}{l}\text { Nuclear factor of activated T cells, } \\
\text { cytoplasmic, calcineurin-dependent } 1\end{array}$ \\
\hline Al385687 & -2.22 & Platelet-derived growth factor, alpha \\
\hline Al450826 & -2.23 & Haematopoietically expressed homeobox \\
\hline Al450410 & -4.89 & $\begin{array}{l}\text { CDC16 cell division } \\
\text { cycle } 16 \text { homolog (S. cerevisiae) }\end{array}$ \\
\hline \multicolumn{3}{|l|}{ Development } \\
\hline Al451692 & 21.55 & T-cell acute lymphocytic leukaemia 1 \\
\hline Al326934 & 3.69 & Fibroblast growth factor receptor 1 \\
\hline Al448320 & 3.05 & Fyn proto-oncogene \\
\hline Al465361 & 2.28 & Tropomyosin 1, alpha \\
\hline Al385632 & 2.26 & Forkhead box D1 \\
\hline Al447777 & 2.13 & MutS homolog 6 (E. coll) \\
\hline Al464342 & 2.12 & Calmegin \\
\hline Al450826 & -2.23 & Haematopoietically expressed homeobox \\
\hline Al666774 & -2.3 & $\begin{array}{l}\text { Internexin neuronal intermediate } \\
\text { filament protein, alpha }\end{array}$ \\
\hline Al413123 & -2.68 & Nucleoporin 50 \\
\hline Al451709 & -2.99 & Signalling intermediate in Toll pathway \\
\hline Al604940 & -17.98 & Gene trap ROSA b-geo 22 \\
\hline \multicolumn{3}{|l|}{ DNA metabolism } \\
\hline Al451530 & 3.60 & Bromodomain, testis-specific \\
\hline Al448557 & 2.26 & $\begin{array}{l}\text { RNA binding motif, single } \\
\text { stranded interacting protein } 1\end{array}$ \\
\hline Al447777 & 2.13 & MutS homolg 6 (E. coli) \\
\hline Al323840 & -2.34 & Enhancer of zeste homolog 2 (Drosophila) \\
\hline Al447451 & -3.75 & $\begin{array}{l}\text { Alpha thalassaemia/mental retardation } \\
\text { syndrome X-linked homolog (human) }\end{array}$ \\
\hline \multicolumn{3}{|l|}{ Electron transport } \\
\hline Al326932 & 14.14 & Cytochrome $c$ oxidase, subunit VIIla \\
\hline Al327319 & 3.78 & Cytochrome -b5 \\
\hline Al893442 & 2.99 & $\begin{array}{l}\text { Cytochrome c oxidase, } \\
\text { subunit Via, polypeptide } 1\end{array}$ \\
\hline \multicolumn{3}{|c|}{ Carbohydrate metabolism } \\
\hline Al323970 & 6.36 & Aldolase $1, \mathrm{~A}$ isoform \\
\hline Al447747 & 3.52 & Phosphofructokinase, platelet \\
\hline Al325909 & 2.44 & Inositol (myo)-1(or 4)-monophosphatase 1 \\
\hline Al451251 & -2.19 & Inositol hexaphosphate kinase 1 \\
\hline Al447731 & -2.32 & $\begin{array}{l}\text { Cytidine monophosphate- } N \text {-acetylneuraminic } \\
\text { acid synthetase }\end{array}$ \\
\hline Al894127 & -2.37 & Galactokinase 1 \\
\hline
\end{tabular}


Transcriptional targets of Bcr-Abl

Table 2. (Continued)

\begin{tabular}{|c|c|c|}
\hline Accession number & Change factor & Description \\
\hline \multicolumn{3}{|l|}{ Haemostasis } \\
\hline Al327250 & 6.30 & Fibrinogen, B beta polypeptide \\
\hline Al464520 & 5.46 & Coagulation factor II (thrombin) receptor \\
\hline \multicolumn{3}{|c|}{ Intracellular signalling } \\
\hline Al448596 & 10.02 & Phospholipase C-like 2 \\
\hline Al449285 & 3.68 & Pleckstrin \\
\hline Al449353 & 3.07 & $\begin{array}{l}\text { Phosphoinositide-3-kinase, catalytic, } \\
\text { gamma polypeptide }\end{array}$ \\
\hline Al596324 & 3.10 & Lin 7 homolog b (Caenorhabditis elegans) \\
\hline Al448320 & 3.05 & Fyn proto-oncogene \\
\hline Al661363 & 2.69 & Downstream of tyrosine kinase 2 \\
\hline Al430952 & 2.16 & Src-like-adaptor 2 \\
\hline \multicolumn{3}{|l|}{ Lipid metabolism } \\
\hline Al448596 & 10.02 & Phospholipase C-like 2 \\
\hline Al327319 & 3.78 & Cytochrome -b5 \\
\hline Al465340 & 2.53 & $\begin{array}{l}\text { ELOVL family member } 6 \text {, elongation } \\
\text { of long chain fatty acids (yeast) }\end{array}$ \\
\hline Al666741 & 2.48 & Phospholipase A2, group XIIB \\
\hline Al528627 & 2.35 & $\begin{array}{l}\text { L-3-hydroxyacyl-Coenzyme } \\
\text { A dehydrogenase, short chain }\end{array}$ \\
\hline Al450829 & -2.01 & Choline/ethanolaminephosphotransferase 1 \\
\hline Al427777 & -2.11 & Phospholipase A2, group V \\
\hline Al447731 & -2.32 & $\begin{array}{l}\text { Cytidine monophosphate- } \mathrm{N} \text {-acetylneuraminic } \\
\text { acid synthetase }\end{array}$ \\
\hline Al430879 & -11.65 & Steryl-sulphatase precursor \\
\hline \multicolumn{3}{|c|}{ Protein biosynthesis } \\
\hline Al450063 & 7.15 & Glutamyl-prolyl-tRNA synthetase \\
\hline Al661153 & 5.33 & Histidyl-tRNA synthetase \\
\hline Al452003 & 4.45 & Mitochondrial ribosomal protein L19 \\
\hline Al429591 & 3.61 & Sialtransferase 5 \\
\hline Al464490 & 2.80 & $\begin{array}{l}\text { Eukaryotic translation initiation } \\
\text { factor } 2 \mathrm{~B} \text {, subunit } 4 \text { delta }\end{array}$ \\
\hline Al449384 & 2.79 & Sialtransferase 8 (alpha-2,8-sialtransferase)d \\
\hline Al465224 & 2.72 & Ribosomal protein L15 \\
\hline Al448557 & 2.26 & $\begin{array}{l}\text { RNA binding motif, } \\
\text { single-stranded interacting protein } 1\end{array}$ \\
\hline Al323719 & 2.05 & $\begin{array}{l}\text { Suppressor of initiator codon mutations, } \\
\text { related sequence } 1 \text { ( } S \text {. cerevisiae) }\end{array}$ \\
\hline \multicolumn{3}{|c|}{ Protein modification } \\
\hline Al327236 & 4.81 & Myotubularin-related protein 7 \\
\hline Al450581 & 4.62 & $\begin{array}{l}\text { Ubiquitin-conjugating enzyme } \\
\text { E2D } 3 \text { (UBC4/5 homolog, yeast) }\end{array}$ \\
\hline Al326934 & 3.69 & Fibroblast growth factor receptor 1 \\
\hline Al429591 & 3.61 & Sialtransferase 5 \\
\hline Al448320 & 3.05 & Fyn proto-oncogene \\
\hline Al449001 & 2.91 & Tubulin tyrosine ligase \\
\hline Al449384 & 2.79 & Sialtransferase 8 (alpha-2,8-sialtransferase)d \\
\hline Al894223 & 2.47 & Mitogen activated protein kinase 13 \\
\hline Al661152 & 2.04 & Mahogunin, ring finger 1 \\
\hline Al385687 & -2.22 & Platelet derived growth factor, alpha \\
\hline Al323840 & -2.34 & Enhancer of zeste homolog 2 (Drosophila) \\
\hline Al662611 & -23.76 & Chaperonin subunit 2 (beta) \\
\hline \multicolumn{3}{|c|}{ Receptor linked signalling } \\
\hline Al451691 & 10.53 & Latrophilin 2 \\
\hline Al449406 & 5.61 & G protein-coupled receptor 68 \\
\hline Al464520 & 5.46 & Coagulation factor II (thrombin) receptor \\
\hline Al327027 & 3.31 & Calmodulin 1 \\
\hline Al465458 & 2.72 & C-type lectin-like receptor 2 \\
\hline Al661363 & 2.69 & Downstream of tyrosine kinase 2 \\
\hline Al450360 & 2.67 & B-cell CLL/lymphoma 9 \\
\hline Al323835 & -2.35 & Purinergic receptor (family A group 5) \\
\hline Al451709 & -2.99 & Signalling intermediate in Toll pathway \\
\hline Al447554 & -3.36 & $\begin{array}{l}\text { CD47 antigen (Rh-related antigen, } \\
\text { integrin-associated signal transducer) }\end{array}$ \\
\hline
\end{tabular}

Table 2. (Continued)

\begin{tabular}{|c|c|c|}
\hline \multicolumn{2}{|c|}{ Accession number Change factor } & Description \\
\hline \multicolumn{3}{|c|}{ Response to stress } \\
\hline Al449406 & 5.61 & G protein-coupled receptor 68 \\
\hline Al448107 & 3.23 & Chemokine (C-C motif) ligand 25 \\
\hline Al528637 & 2.77 & Beta-2 microglobulin \\
\hline Al447777 & 2.13 & MutS homolog 6 (E. coll) \\
\hline Al447451 & -3.75 & $\begin{array}{l}\text { Alpha thalassaemia/mental retardation } \\
\text { syndrome X-linked homolog (human) }\end{array}$ \\
\hline Al323815 & -4.14 & Immunoglobulin joining chain \\
\hline \multicolumn{3}{|c|}{ RNA metabolism } \\
\hline Al450063 & 7.15 & Glutamyl-prolyl-tRNA synthetase \\
\hline Al661153 & 5.33 & Histidyl-tRNA synthetase \\
\hline Al451874 & 4.92 & $\begin{array}{l}\text { PRP4 pre-mRNA processing } \\
\text { factor } 4 \text { homolog (yeast) }\end{array}$ \\
\hline Al661408 & 2.29 & CUG triplet repeat, RNA binding protein 2 \\
\hline Al448557 & 2.26 & $\begin{array}{l}\text { RNA binding motif, single stranded } \\
\text { interacting protein } 1\end{array}$ \\
\hline Al448990 & 2.06 & $\begin{array}{l}\text { Splicing factor, arginine/serine-rich } \\
16 \text { (suppressor-of-white-apricot homolog, } \\
\text { Drosophila) }\end{array}$ \\
\hline Al449004 & -2.88 & Heterogeneous nuclear ribonucleoprotein $\mathrm{A} 2 / \mathrm{B} 1$ \\
\hline \multicolumn{3}{|c|}{ Transcription } \\
\hline Al451692 & 21.55 & T-cell acute lymphocytic leukaemia 1 \\
\hline Al448727 & 16.03 & Core promoter element binding protein \\
\hline Al447646 & 6.98 & General transcription factor II A, 1 \\
\hline Al465448 & 3.28 & $\begin{array}{l}\text { SWI/SNF related, matrix associated, } \\
\text { actin-dependent regulator of chromatin, } \\
\text { subfamily e, member } 1\end{array}$ \\
\hline Al451871 & 3.17 & Interleukin enhancer binding factor 3 \\
\hline Al448895 & 3.14 & Polymerase (RNA) mitochondrial (DNA directed) \\
\hline Al327031 & 2.36 & GLI-Kruppel family member HKR3 \\
\hline Al448284 & 2.36 & X-box binding protein 1 \\
\hline Al385632 & 2.26 & Forkhead box D1 \\
\hline Al596340 & 2.14 & Pbx/knotted 1 homeobox \\
\hline Al447566 & 2.03 & $\begin{array}{l}\text { General transcription factor } \| E_{\text {, }} \\
\text { polypeptide } 1 \text { (alpha subunit) }\end{array}$ \\
\hline Al449492 & -2.03 & $\begin{array}{l}\text { Nuclear factor of activated T-cells, } \\
\text { cytoplasmic, calcineurin-dependent } 1\end{array}$ \\
\hline Al427453 & -2.08 & Programmed cell death protein 7 \\
\hline Al415454 & -2.16 & Transcription factor CP2-like 3 \\
\hline Al450826 & -2.23 & Haematopoietically expressed homeobox \\
\hline Al323840 & -2.34 & Enhancer of zeste homolog 2 (Drosophila) \\
\hline Al451709 & -2.99 & Signalling intermediate in Toll pathway \\
\hline Al661335 & -4.36 & Structure specific recognition protein 1 \\
\hline Al451044 & -10.78 & Ngfi-A binding protein 1 \\
\hline \multicolumn{3}{|l|}{ Transport } \\
\hline Al413193 & 4.19 & $\begin{array}{l}\text { Solute carrier family } 28 \\
\text { (sodium-coupled nucleoside } \\
\text { transporter), member } 2\end{array}$ \\
\hline Al451307 & 3.66 & Karyopherin (importin) alpha 4 \\
\hline Al666360 & 3.37 & $\begin{array}{l}\text { Solute carrier family } 14 \\
\text { (urea transporter), member } 1\end{array}$ \\
\hline Al661871 & 2.66 & Syntaxin 7 \\
\hline Al327160 & 2.57 & $\begin{array}{l}\text { Coatomer protein complex, } \\
\text { subunit zeta } 2\end{array}$ \\
\hline Al385632 & 2.26 & Forkhead box D1 \\
\hline Al449492 & -2.03 & $\begin{array}{l}\text { Nuclear factor of activated T cells, } \\
\text { cytoplasmic, calcineurin-dependent } 1\end{array}$ \\
\hline Al323390 & -2.25 & $\begin{array}{l}\text { Solute carrier family } 6 \text { (neurotransmitter } \\
\text { transporter, glycine), member } 9\end{array}$ \\
\hline Al427044 & -2.41 & Sec 61, alpha subunit 2 (S. cerevisiae) \\
\hline Al413123 & -2.68 & Nucleoporin 50 \\
\hline Al447554 & -3.36 & $\begin{array}{l}\text { CD47 antigen (Rh-related antigen, } \\
\text { integrin-associated signal transducer) }\end{array}$ \\
\hline
\end{tabular}




\section{Hickey and Cotter}

levels in each of these functional categories is shown in Table 2 along with the GenBank accession number and the change factor observed in $\mathrm{C} 4$ cells.

\section{Validation of array results by real-time RT-PCR}

In order to confirm the results seen in the microarray experiments, real-time RT-PCR was carried out for multiple genes showing increased expression in $\mathrm{C} 4$ cells. One of the clinical characteristics of CML cells is adhesion independence (5). As such we confirmed the upregulation of gamma parvin (Fig. 3A). Gamma parvin is member of a family of actin-binding focal adhesion proteins (22). To date this family of proteins have not been implicated in CML. It is also of interest that several genes involved in cellular proliferation were upregulated in $\mathrm{C} 4$ vs. $32 \mathrm{D}$ cells. It is thought that Bcr-Abl contributes to the expansion of leukaemic cells
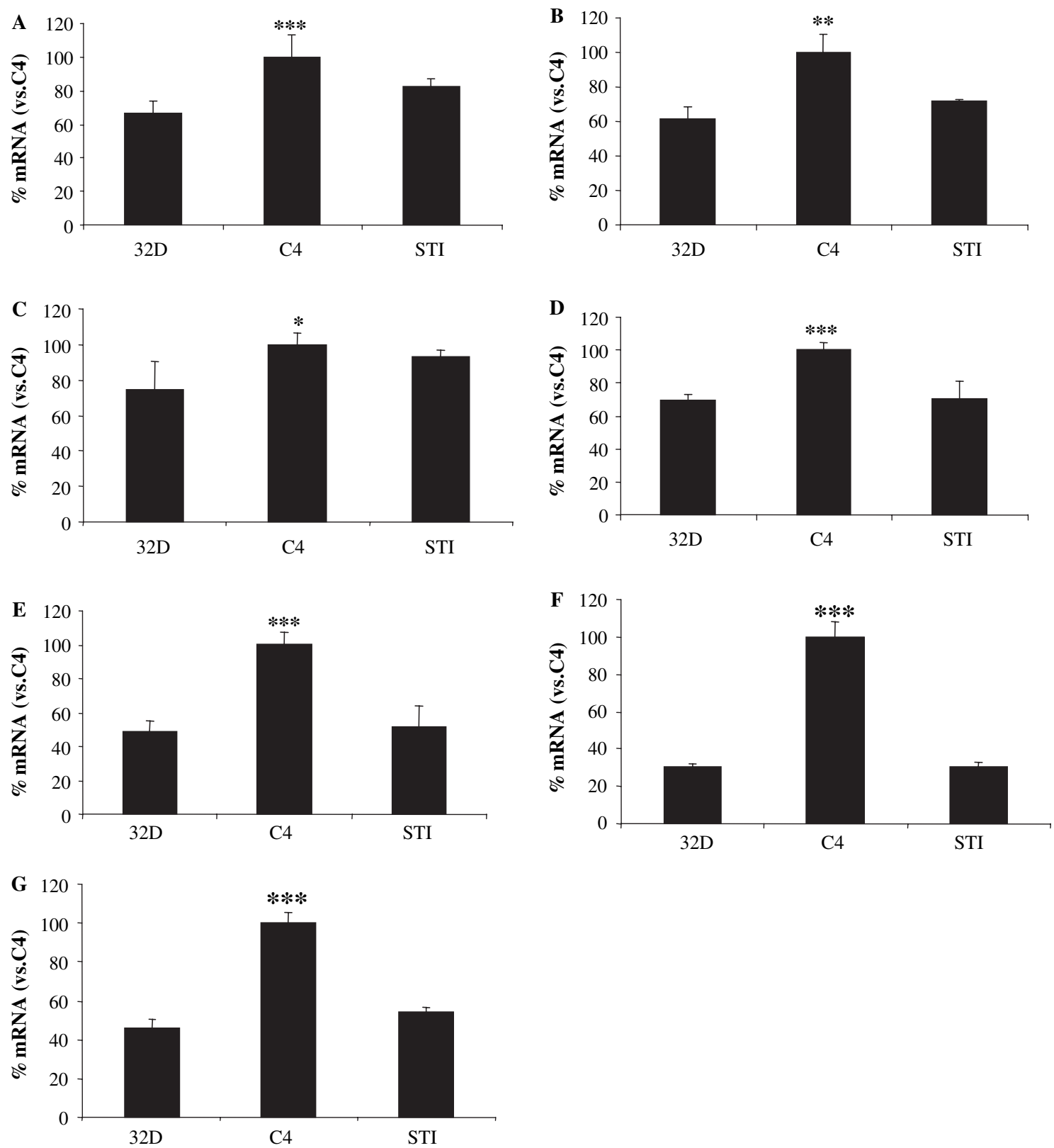

Fig. 3. Confirmation of array results by real-time RT-PCR. Real-time RT-PCR experiments using cDNA from 32D, untreated C4 cells and C4 cells treated for $48 \mathrm{~h}$ with $1 \mu \mathrm{M}$ STI571 (STI) show expression levels of (A) gamma parvin, (B) calmodulin 1, (C) myc-induced nuclear antigen (Mina), (D) cytochrome $c$ oxidase subunit VIIIa (COX VIIIa), (E) aldolase 1A, (F) phosphofructokinase, and (G) PI3Kgamma. Data are presented as the mean and standard error of the mean for independent experiments $(n=3)$. Statistical analysis was performed using an unpaired Student's $t$-test $(* P<0.05$, $* * P<0.01, * * * P<0.005$ compared with levels in $32 \mathrm{D}$ cells). 
through enhanced proliferation (23). C4 cells showed increased levels of Calmodulin 1 and Myc-induced nuclear antigen (Mina) among other genes reported to be involved in cellular proliferation. Real-time RT-PCR was performed for both of these genes comparing levels in 32D and $\mathrm{C} 4$ cells. In both cases the increased expression seen on microarrays was verified (Fig. 3B,C).

Cytochrome $c$ oxidase subunit VIIIa (COX VIIIa) is a nuclear-encoded protein that is a critical component of the oxidative phosphorylation pathway. Microarray analysis showed this gene to be upregulated in $\mathrm{C} 4$ cells and this was confirmed by RT-PCR (Fig. 3D). The mitochondrion-encoded COX subunits I-III have previously been shown to be differentially expressed in a Bcr-Abl positive cell line (24), suggesting a role for differential COX expression in CML. Many genes encoding enzymes involved in carbohydrate metabolism were also found to be differentially expressed in $\mathrm{C} 4$ cells. This is of specific interest as it has previously been shown that treatment of K562 cells with the Bcr-Abl inhibitor STI571 results in altered metabolic activity (25). We confirmed the upregulation of aldolase $1 \mathrm{~A}$ and phosphofructokinase in $\mathrm{C} 4$ cells (Fig. 3E,F), both of which are involved in glycolysis. The increased expression of phosphofructokinase is of particular interest as this enzyme catalyses the irreversible transfer of a phosphate from ATP to fructose-6-phosphate. Because of the irreversible nature of this step, phosphofructokinase is a key regulatory enzyme for glycolysis.

PI3K has been repeatedly implicated downstream of Bcr-Abl in studies from both mouse (26) and cell line models (14) of CML. However, our finding that PI3K $\gamma$ expression is upregulated by Bcr-Abl represents not only the first report of altered PI3K expression in CML, but also the first potential involvement of this specific isoform of PI3K. Therefore, we confirmed the increased expression of $\mathrm{PI} 3 \mathrm{~K} \gamma$ seen in $\mathrm{C} 4$ cells (Fig. 3G). $\mathrm{PI} 3 \mathrm{~K} \gamma$ is a class $\mathrm{I}_{\mathrm{B}}$ member of the PI3K family and has not to date been implicated in CML. In all PCR experiments, the expression level of each gene was also analysed in $\mathrm{C} 4$ cells treated with the Bcr-Abl inhibitor STI571 (Fig. 3). As shown, in all cases this treatment resulted in expression levels of the particular gene being reverted to those seen in $32 \mathrm{D}$ cells. Therefore, confirming that the altered expression seen is due to Bcr-Abl activity.

\section{Use of STI571 to confirm results in K562 cells}

In order to confirm that the increases seen in gene expression in $\mathrm{C} 4$ cells are not unique to this cell line, we also employed a human CML cell line
$\mathrm{K} 562$. This is an erythroleukaemia cell line derived from a patient in the blast crisis phase of CML (27). K562 cells were treated with $0.5 \mu \mathrm{M}$ STI6571 for $24 \mathrm{~h}$ in order to inhibit Bcr-Abl tyrosine kinase activity. This concentration was chosen as it resulted in a complete reduction in phosphotyrosine levels as determined by PY20 antibody binding (Fig. 4A). It was also determined that this concentration was not significantly cytotoxic to the cells by measurement of PI uptake on a FACScan flow cytometer (Fig. 4B). mRNA was prepared from both untreated and STI571-treated K562 cells. Real-time RT-PCR was then carried out for the seven genes analysed in $32 \mathrm{D}$ and $\mathrm{C} 4$ cells. In the case of six of these genes - calmodulin 1 (Fig. 5A), Myc-induced nuclear antigen (Fig. 5B), COX VIIIa (Fig. 5C), aldolase 1A (Fig. 5D), phosphofructokinase (Fig. 5E) and PI3K $\gamma$ (Fig. 5F) - we found that treatment with STI571 resulted in reduced expression levels of these genes. This suggests that in $\mathrm{K} 562$ cells Bcr-Abl activity is required for the high levels of expression seen, thus corroborating in a human CML cell line the results seen in a murine
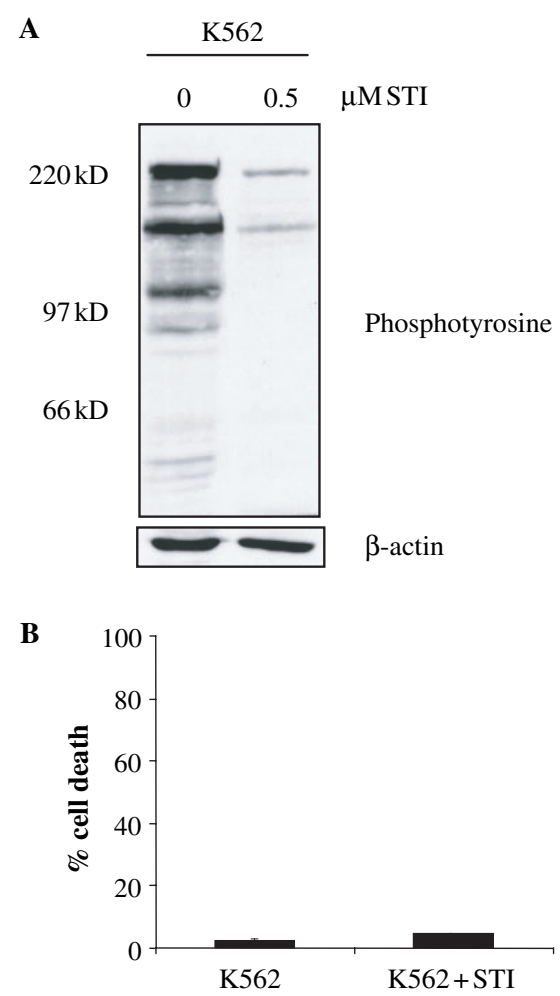

Fig. 4. Use of STI571 to inhibit Bcr-Abl activity in K562 cells. (A) Western blot analysis of phosphotyrosine levels in total cell lysates from K562 cells treated with the indicated concentrations of STI571 (STI) for $24 \mathrm{~h}$. (B) Untreated K562 cells and K562 cells treated for $24 \mathrm{~h}$ with $0.5 \mu \mathrm{M}$ STI571 (STI) were assessed for cell death by PI uptake and flow cytometry. Data are presented as the mean and standard error of the mean for independent experiments $(n=3)$. 

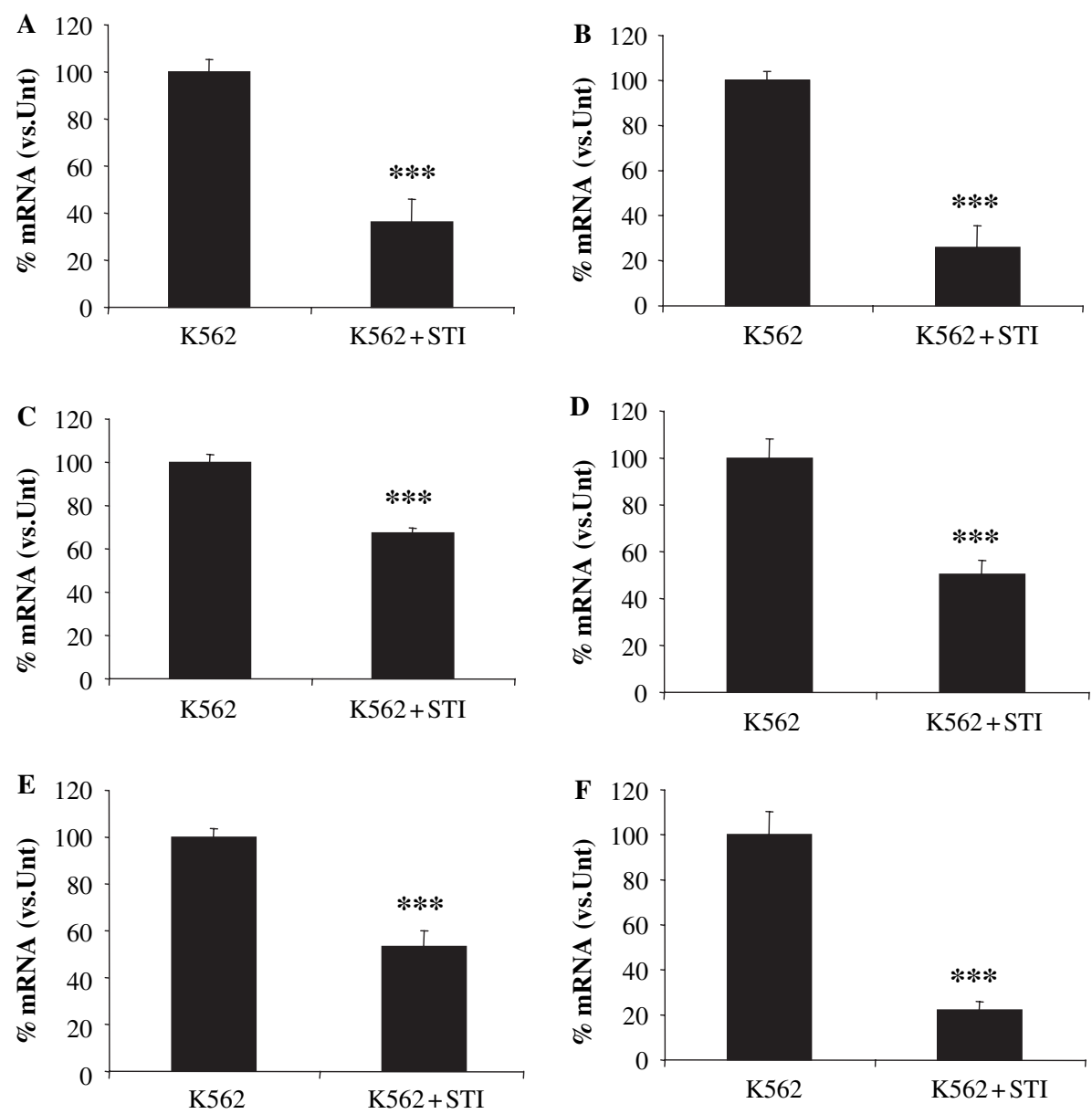

Fig. 5. Confirmation of array results by real-time RT-PCR in K562 cells. Real time RT-PCR experiments using cDNA from untreated K562 cells and K562 cells treated for $24 \mathrm{~h}$ with $0.5 \mu \mathrm{M}$ STI571 (STI) show expression levels of (A) calmodulin 1, (B) myc-induced nuclear antigen (Mina), (C) cytochrome $c$ oxidase subunit VIIIa (COX VIIIa), (D) aldolase 1A, (E) phosphofructokinase, and (F) PI3Kgamma. Data are presented as the mean and standard error of the mean for independent experiments $(n=3)$. Statistical analysis was performed using an unpaired Student's $t$-test $(* * * P<0.005$ compared with levels in untreated K562 cells).

model. For the remaining gene - gamma parvin we failed to detect expression in K562 cells in the presence or absence of STI571.

\section{Analysis of proliferation in $32 \mathrm{D}$ and $\mathrm{C} 4$ cells}

It has been reported in some studies that Bcr-Abl leads to increased proliferation of cells due to alterations in cell cycle (28). However, other studies have failed to find any affect on cellular proliferation rates in response to Bcr-Abl (29). As we found numerous genes involved in cell proliferation to be differentially expressed in our model of CML, we determined the growth rate of 32D and $\mathrm{C} 4$ cells. This was achieved by counting cell numbers from aliquots at time points over $3 \mathrm{~d}$. As shown in Fig. 6A, we found no difference in the growth rate of $\mathrm{C} 4$ cells compared with 32D cells under normal culture conditions (32D cells were grown in the presence of IL-3). However, when both cell lines were cultured in the absence of IL-3 we found a marked decrease in the proliferation rate of 32D cells (Fig. 6B). This may suggest that the upregulation of genes involved in cellular proliferation allows the Bcr-Abl-expressing $\mathrm{C} 4$ cells to grow in the absence of cytokine.

Bcr-Abl expression results in increased glycolysis in C4 cells in a PI3K-dependent manner

We found the expression of a number of genes encoding glycolytic enzymes to be upregulated in the Bcr-Abl-expressing $\mathrm{C} 4$ cells when compared with the parental $32 \mathrm{D}$ cells. As such we measured the rate of glycolysis in these cells. This was achieved by measuring the rate of conversion of ${ }^{5-}{ }^{3} \mathrm{H}$ glucose to ${ }^{3} \mathrm{H}_{2} \mathrm{O}$ which is dependent on the rate of breakdown of glucose to phosphoenolpyruvate. Our results show that the rate of glucose utilisation is significantly increased in C4 cells 
A
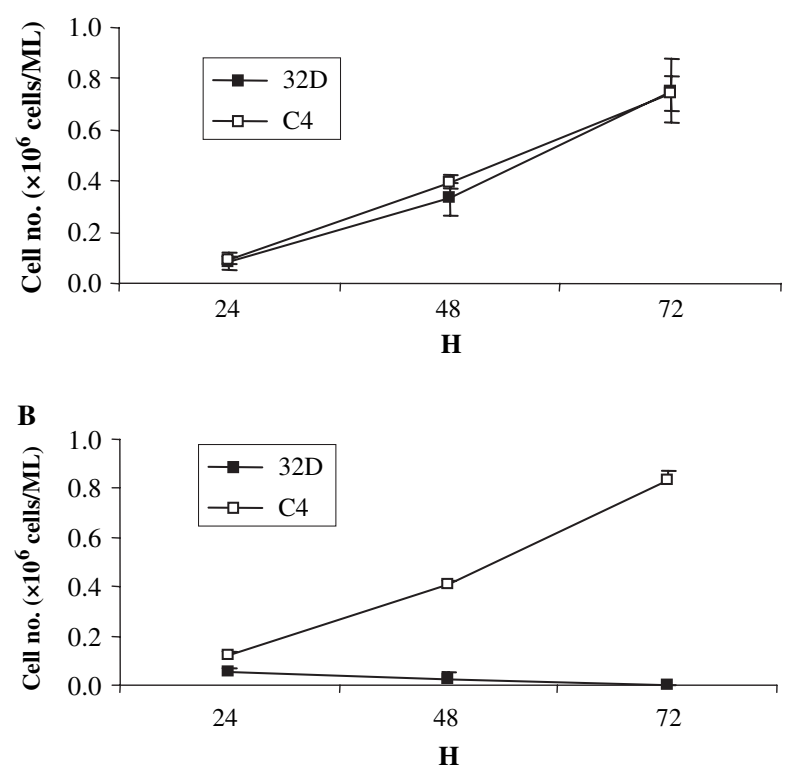

Fig. 6. Analysis of proliferation rates in 32D and C4 cells. Cell number (indicative of proliferation) for $32 \mathrm{D}$ and $\mathrm{C} 4$ cells was assessed by trypan blue exclusion for $3 \mathrm{~d}$. (A) 32D cells were cultured in the presence of IL-3, C4 cells were cultured in the absence of IL-3. (B) Both 32D and C4 cells were cultured in the absence of IL-3. Data represent the mean and standard error of the mean for independent experiments $(n=4)$.

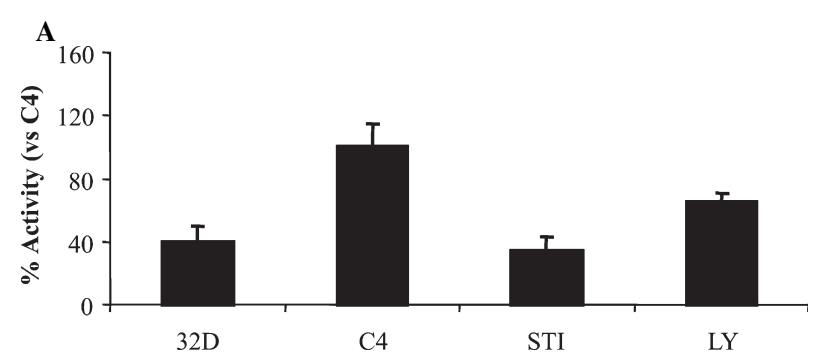

B

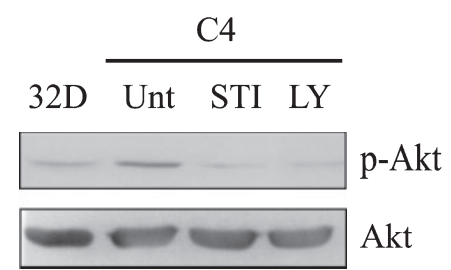

Fig. 7. Bcr-Abl expression leads to increased glycolysis in $\mathrm{C} 4$ cells in a PI3K-dependent manner. (A) The rate of glucose metabolism in 32D and C4 cells and C4 cells treated for $48 \mathrm{~h}$ with $1 \mu \mathrm{M}$ STI571 (STI) or $20 \mu \mathrm{M}$ LY294002 (LY) was measured by the conversion of $5-{ }^{3} \mathrm{H}$ glucose to ${ }^{3} \mathrm{H}_{2} \mathrm{O}$. Data represent the mean and standard error of the mean for independent experiments $(n=3)$. (B) Western blot analysis of phospho-AKT (ser 473) levels in total cell lysates from 32D, untreated C4 cells (Unt) and C4 cells treated for $48 \mathrm{~h}$ with $1 \mu \mathrm{M}$ STI571 (STI) or $20 \mu \mathrm{M}$ LY294002 (LY). AKT antibody binding demonstrates equal protein loading.

(Fig. 7A). In fact a 2.5-fold increase in the rate of glycolysis was observed. We also demonstrate that this increased activity is dependent on the tyrosine kinase activity of $\mathrm{Bcr}-\mathrm{Abl}$ in $\mathrm{C} 4$ cells as treatment with STI571 reduces glycolytic activity in C4 cells to levels equivalent to $32 \mathrm{D}$ cells. It has been shown recently by Kim et al. (30) that the glucose pathway is involved in increased production of reactive oxygen species (ROS) in CML cells. This study also determined that the PI3K pathway was at least in part responsible for the increased levels of ROS, suggesting that activation of the PI3K pathway is required for increased glycolysis. We show that in our system, the increased rate of glycolysis observed in $\mathrm{C} 4$ cells can be significantly reduced by treatment of these cells with the PI3K inhibitor LY294002 (Fig. 7A). The reduction in glycolytic activity following this treatment is approximately 1.5-fold but this level of activity is still higher than that seen in the 32D cell line suggesting that other pathways may also be involved. A potential candidate is mTOR (molecular target of rapamycin), as activation of this kinase was shown to be required along with PI3K for the increased ROS shown by Kim et al. (30). It was confirmed that PI3K activity was inhibited by the concentration of LY294002 used (Fig. 7B). Levels of phosphorylated AKT were used a measure of PI3K activity and, as shown C4 cells display a significantly higher level of activity than do 32D cells. This activity can be reduced by both the Bcr-Abl-specific inhibitor STI571 and the PI3K inhibitor LY294002.

p110 $\gamma$ protein expression is increased in a Bcr-Abl-dependent manner, but is not involved in glycolysis

The increased expression of PI3K $\gamma$ seen in $\mathrm{C} 4$ cells is of particular interest as PI3K has been implicated downstream of Bcr-Abl in studies from both mouse (26) and cell line models (31) of CML. However, very little is known about the particular PI3K isoforms involved in Bcr-Abl-dependent signalling. We confirmed increased expression of PI3K $\gamma$ protein in $\mathrm{C} 4$ cells compared with parental 32D cells by Western blotting of whole cell lysates (Fig. 8A). It is also shown that treatment of $\mathrm{C} 4$ cells with STI571 results in a decrease in PI3K $\gamma$ levels, confirming the requirement for Bcr-Abl tyrosine kinase activity. As we had found that Bcr-Abl tyrosine kinase activity also leads to increased PI3K $\gamma$ mRNA in K562 cells we analysed levels of PI3K $\gamma$ protein in untreated and STI571-treated cells. Figure $8 \mathrm{~B}$ shows that inhibition of Bcr-Abl activity also results in reduced $\mathrm{PI} 3 \mathrm{~K} \gamma$ protein levels in K562 cells. Figure 7A demonstrates that PI3K activity is required for increased glycolytic activity in $\mathrm{C} 4$ cells. As we found increased expression of the specific p110 $\gamma$ isoform of PI3K in these cells we assessed its potential involvement in glycolysis. In order to achieve this we transfected $\mathrm{C} 4$ cells with a 
$\mathbf{A}$

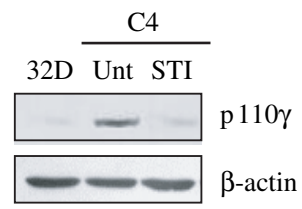

B
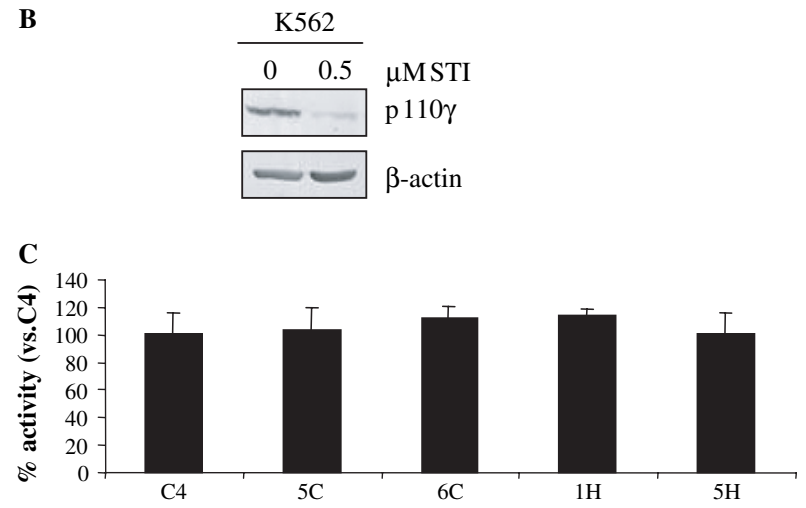

Fig. 8. p110 $\gamma$ protein expression is increased in a Bcr-Abldependent manner, but is not involved in glycolysis. (A) Western blot analysis of p110 $\gamma$ levels in total cell lysates from 32D, untreated C4 cells (Unt) and C4 cells treated for $48 \mathrm{~h}$ with $1 \mu \mathrm{M}$ STI571 (STI). (B) Western blot analysis of p110 levels in total cell lysates from untreated K562 cells and K 562 cells treated for $24 \mathrm{~h}$ with $0.5 \mu \mathrm{M}$ STI571 (STI). In (A) and (B) actin antibody binding demonstrates equal protein loading. (C) The rate of glucose metabolism in $\mathrm{C} 4$ cells and four clones stably expressing dnp $110 \gamma(5 \mathrm{C}, 6 \mathrm{C}, 1 \mathrm{H}$, $5 \mathrm{H})$ was measured by the conversion of $5-{ }^{3} \mathrm{H}$ glucose to ${ }^{3} \mathrm{H}_{2} \mathrm{O}$. Data are presented as the mean and standard error of the mean for independent experiments $(n=3)$.

dominant negative, kinase-deficient mutant PI3K $\gamma$ (K832R). Clones stably expressing the plasmid were selected by serial dilution in media containing G418. Four representative clones were chosen, namely $5 \mathrm{C}, 6 \mathrm{C}, 1 \mathrm{H}$ and $5 \mathrm{H}$. However, as Fig. $8 \mathrm{C}$ shows we found no difference in the rate of glycolysis in these cells compared with $\mathrm{C} 4$ cells suggesting that $\mathrm{PI} 3 \mathrm{~K} \gamma$ does not play a role in glycolysis, or if it does, this role is redundant and other PI3K isoforms can compensate in the absence of PI3K $\gamma$.

\section{Discussion}

The constitutive tyrosine kinase activity of the BcrAbl fusion protein is the causative agent of CML. While many of the pathways activated downstream of Bcr-Abl are known, very little is known about the affects that Bcr-Abl has on gene expression. The data presented here demonstrate the transcriptional profiling of $32 \mathrm{D}$ cells, a murine myeloid progenitor cell line, vs. a transfected clone of 32D cells expressing high levels of p210 Bcr-Abl (C4 cells). This study identified 138 genes of known function that showed a greater than twofold difference in expression in response to Bcr-Abl-mediated signal- ling. The expression of other cDNAs was also found to be deregulated, however, these represented ESTs for which no known genes could be identified. Interestingly we found that more genes showed increased rather than decreased expression in response to Bcr-Abl. The identified genes were subgrouped into different, although partially overlapping, categories based on the function of the encoded proteins. These genes may play a role in the transformation by Bcr-Abl resulting in the adhesion independence, growth factor independence and drug resistance of CML cells.

A number of genes of particular interest were chosen and the upregulation seen on the microarrays was confirmed by real-time RT-PCR. While our model of CML allows us to compare directly the effects of Bcr-Abl expression between 32D and $\mathrm{C} 4$ cells, this model is subject to the limitations of any cell line model. Therefore, in RT-PCR experiments we have used the Bcr-Abl-specific inhibitor STI571 in order to confirm that the differences seen are in fact due to Bcr-Abl tyrosine kinase activity. That is, for all genes, treatment of $\mathrm{C} 4$ cells with STI571 resulted in a decrease of mRNA levels back to those seen in $32 \mathrm{D}$ cells. This further verifies that the alterations in expression seen are a direct consequence of $\mathrm{Bcr}-\mathrm{Abl}$ expression in $\mathrm{C} 4$ cells. In addition, in order to confirm that the changes in expression seen are not unique to this model cell line we confirmed the Bcr-Abl-dependent upregulation of six genes in K562 cells (a human CML cell line) by real-time RT-PCR.

Given the importance of adhesion independence in CML it is of interest that several genes involved in cellular adhesion were differentially expressed in $\mathrm{C} 4$ cells. Among these were gamma parvin (a focal adhesion protein) and cadherin 5. Cadherins are a family of proteins necessary for cell-cell attachment. Methylation of E-cadherin (cadherin 1) has previously been reported in childhood ALL (32). These results may suggest a general role for the altered expression of cadherin genes in leukaemia. Cytochrome $c$ oxidase subunit VIIIa was also found to upregulated in $\mathrm{C} 4$ cells and this was confirmed by RT-PCR. COX is found as a dimer in mammalian cells with each monomer being composed of 13 subunits. Subunits I-III comprise the catalytic core of the enzyme and are all synthesised from mitochondrial DNA. The remaining subunits (IV-VIII) are synthesised from cellular nuclear DNA. While the mitochondrion-encoded COX subunits I-III have previously been shown to be differentially expressed following treatment of K562 cells with STI571 (24), our work represents the first to demonstrate a link between Bcr-Abl and any of the nuclear-encoded subunits. Herrmann et al. (33) recently noted a significant shift in the 
relative concentrations of nuclear encoded COX subunits compared with mitochondrial encoded COX subunits during the progression of prostate cancer. This may suggest a role for COX in cancer in general with differential expression of subunits being of great importance.

To date a number of studies have reported altered transcription of genes in response to Bcr$\mathrm{Abl}$ expression. These reports include the upregulation of Bcl- $\mathrm{x}_{\mathrm{L}}(34)$, c-myc (35) and $\mathrm{PKC}_{l}$ (36) and the downregulation of TRAIL (tumour necrosis factor-like apoptosis-inducing ligand) (37). These genes were not represented on the microarrays used in our studies and as such we cannot confirm these findings in our system. In addition to these studies investigating the altered expression of specific genes downstream of Bcr-Abl, other studies using DNA microarray analysis have demonstrated that the expression of PIASy (protein inhibitor of activated STAT) is downregulated in association with CML progression from chronic phase to blast crisis (38). Hakansson et al. (39) have also recently shown the upregulation of CEACAM1 (CD66a) by microarray comparisons using U937 cells expressing inducible p210 Bcr-Abl. These studies highlight the benefit of array technology in the identification of novel genes involved in Bcr-Abl-mediated transformation.

There have been several reports of PI3K involvement in signalling downstream of the Bcr-Abl oncogene $(8,31)$ however, differential expression of any of the PI3K subunits has not been previously reported. Therefore it is of potentially great significance that we find the expression of the class $I_{B}$ catalytic subunit p110 $\gamma$ to be increased in $\mathrm{C} 4$ cells. This also represents the first potential involvement of this particular isoform of PI3K in CML, at any level. PI3K $\gamma$ differs from the class $\mathrm{I}_{\mathrm{A}}$ members in that it associates with a p101 adaptor rather than a p85 regulatory subunit, and also in that it is reported to be activated mainly by $\mathrm{G}$ proteincoupled receptors (40) while the p85-associated PI3Ks are activated by tyrosine kinases.

The chronic phase of CML is characterised by the expansion of both mature and immature myeloid cells. This increase in cell number is likely due to an imbalance between proliferation and apoptotic signals. In general, however, the proliferative effect of Bcr-Abl remains unclear. Here we show that ectopic expression of Bcr-Abl in 32D cells results in the altered expression of a large number of genes with a reported function in cellular proliferation. These genes include Myc-induced nuclear antigen (Mina), a direct target gene of Myc. This is not surprising as c-Myc has been shown to play a critical role in transformation by Bcr-Abl (41). Other upregulated cell proliferation genes included both cyclin G2 and cyclin D3, both involved in cell cycle progression. However, while cyclin D3 expression leads to increased proliferation (42), cyclin $\mathrm{G} 2$ has been shown to inhibit cell cycle progression (43). Due to these seemingly contradictory results we measured the growth rate of 32D and $\mathrm{C} 4$ cells in order to determine the effect of Bcr-Abl on proliferation. As shown we found that Bcr-Abl expression does not result in increased proliferation under normal culture conditions. A similar result was shown recently by Hakansson et al. (39), where they in fact demonstrated that inducible expression of p210 Bcr-Abl in U937 cells led to a slight decrease in proliferation. Studies have also failed to show in vivo that CML cells proliferate faster than do their normal counterparts (44). As such, it would seem that our inability to detect increased proliferation in a cell line model of $\mathrm{CML}$, in fact mimics the disease in vivo. However, we did note a marked difference in rates of proliferation when $32 \mathrm{D}$ cells were cultured in the absence of IL-3. This may suggest that the increased expression of proliferation-associated genes is necessary for the growth factor-independent growth seen in CML cells.

It has previously been shown that treatment of K562 cells with the Bcr-Abl inhibitor STI571 results in altered metabolic activity (25). We found that, in our model of CML, genes encoding key enzymes in glycolysis are upregulated by Bcr-Abl. We confirmed the upregulation of these genes by real-time PCR and also demonstrate that $\mathrm{C} 4$ cells display a higher rate of glycolytic activity than do the 32D cells and this increased activity is dependent on PI3K activity. As we found increased expression of the p110 $\gamma$-specific isoform of PI3K in Bcr-Abl-positive cells, we investigated its potential involvement in glycolysis using a dominant negative plasmid. However, we found no difference in the rate of glycolysis between $\mathrm{C} 4$ cells and $\mathrm{C} 4$ cells transfected with dnp110 $\gamma$. This suggests that p110 $\gamma$ either has no role in glycolysis in these cells, or it may have a non-redundant role, whereby in the absence of $\mathrm{p} 110 \gamma$, other PI3K isoforms can compensate for its activity. Increased glycolysis has been associated with cancer cells for some time (45) and recently, Munoz-Pinedo et al. (46) have shown that a reduction of this activity can sensitise tumour cells to apoptosis through the caspase 8/death receptor pathway.

While the Bcr-Abl-specific inhibitor STI571 (Gleevec) has been reported to have a significant clinical effect when used to treat patients in both the chronic and blast crisis phases of CML (47), many patients in blast crisis relapse after a relatively short period of treatment (48). This suggests that if patients are to be treated successfully new targets 
for therapy need to be found and validated. It is hoped that the identification of new genes and signalling pathways affected by Bcr-Abl will help to achieve this goal.

\section{Acknowledgements}

This work was supported by the Higher Education Authority of Ireland, the Children's Leukaemia Research Project and Cancer Research Ireland. We thank Dr Karen England and Dr Francesca Doonan for helpful discussions and critical reading of the manuscript.

\section{References}

1. Rowley JD. Chromosome abnormalities in the acute phase of CML. Virchows Arch B Cell Pathol 1978;29:57-63.

2. Melo JV. The diversity of BCR-ABL fusion proteins and their relationship to leukemia phenotype. Blood 1996;88:2375-2384.

3. Kabarowski JH, Witte ON. Consequences of BCR-ABL expression within the hematopoietic stem cell in chronic myeloid leukemia. Stem Cells 2000;18:399-408.

4. Mandanas RA, Boswell HS, Lu L, Leibowitz D. BCR/ ABL confers growth factor independence upon a murine myeloid cell line. Leukemia 1992;6:796-800.

5. Salgia R, Li JL, Ewaniuk DS, Pear W, Pisick E, Burky SA, ERnst T, SAtTler M, Chen LB, Griffin JD. BCR/ ABL induces multiple abnormalities of cytoskeletal function. J Clin Invest 1997;100:46-57.

6. Keeshan K, Mills Ki, Cotter TG, McKenna SL. Elevated Bcr-Abl expression levels are sufficient for a haematopoietic cell line to acquire a drug-resistant phenotype. Leukemia 2001;15:1823-1833.

7. Hoover RR, Gerlach MJ, Koh EY, Daley GQ. Cooperative and redundant effects of STAT5 and Ras signaling in $\mathrm{BCR} / \mathrm{ABL}$ transformed hematopoietic cells. Oncogene 2001;20:5826-5835.

8. Skorski T, Bellacosa A, Nieborowska-Skorska M et al. Transformation of hematopoietic cells by BCR/ABL requires activation of a PI-3k/Akt-dependent pathway. EMBO J 1997;16:6151-6161.

9. Chai SK, Nichols GL, Rothman P. Constitutive activation of JAKs and STATs in BCR-Abl-expressing cell lines and peripheral blood cells derived from leukemic patients. J Immunol 1997;159:4720-4728.

10. Kisseleva T, Bhattacharya S, Braunstein J, Schindler CW. Signaling through the JAK/STAT pathway, recent advances and future challenges. Gene 2002;285:1-24.

11. Shuai K, Halpern J, ten Hoeve J, Rao X, Sawyers Cl. Constitutive activation of STAT5 by the BCR-ABL oncogene in chronic myelogenous leukemia. Oncogene 1996;13:247-254.

12. Ilaria RL Jr, VAN EtTen RA. P210 and P190(BCR/ABL) induce the tyrosine phosphorylation and DNA binding activity of multiple specific STAT family members. J Biol Chem 1996;271:31704-31710.

13. Cortez D, Stoica G, Pierce JH, Pendergast AM. The BCR-ABL tyrosine kinase inhibits apoptosis by activating a Ras-dependent signaling pathway. Oncogene 1996;13:2589-2594.

14. Sonoyama J, Matsumura I, Ezoe S et al. Functional cooperation among Ras, STAT5, and phosphatidylinositol 3-kinase is required for full oncogenic activities of BCR/ ABL in K562 cells. J Biol Chem 2002;277:8076-8082.

15. Coller Ha, Grandori C, Tamayo P, Colbert T, Lander ES, Eisenman RN, Golub TR. Expression analysis with oligonucleotide microarrays reveals that MYC regulates genes involved in growth, cell cycle, signaling, and adhesion. Proc Natl Acad Sci USA 2000;97:3260-3265.

16. Zavadil J, Bitzer M, Liang D, Yang YC, Massimi A, Kneitz S, Piek E, Bottinger EP. Genetic programs of epithelial cell plasticity directed by transforming growth factor-beta. Proc Natl Acad Sci USA 2001;98:66866691.

17. Hegde P, Qi R, Abernathy K, Gay C, Dharap S, Gaspard R, Hughes Je, Snesrud E, Lee N, Quackenbush J. A concise guide to cDNA microarray analysis. Biotechniques 2000;29:548-550, 552-554, 556 passim.

18. Al-Shahrour F, Diaz-Uriarte R, Dopazo J. Fatigo: a web tool for finding significant associations of Gene Ontology terms with groups of genes. Bioinformatics 2004;20:578-580.

19. Ashcroft SJ, Weerasinghe lC, Bassett JM, Randle PJ. The pentose cycle and insulin release in mouse pancreatic islets. Biochem J 1972;126:525-532.

20. Rowley JD. Letter: A new consistent chromosomal abnormality in chronic myelogenous leukaemia identified by quinacrine fluorescence and Giemsa staining. Nature 1973;243:290-293.

21. Carroll M, Ohno-Jones S, Tamura S, Buchdunger E, Zimmermann J, Lydon NB, Gilliland DG, Druker BJ. CGP 57148, a tyrosine kinase inhibitor, inhibits the growth of cells expressing BCR-ABL, TEL-ABL, and TELPDGFR fusion proteins. Blood 1997;90:4947-4952.

22. Olski TM, Noegel AA, Korenbaum E. Parvin, a 42 kDa focal adhesion protein, related to the alpha-actinin superfamily. J Cell Sci 2001;114:525-538.

23. Deininger MW, Goldman JM, Melo JV. The molecular biology of chronic myeloid leukemia. Blood 2000;96:33433356.

24. Grandjean F, Bremaud L, Robert J, Ratinaud MH. Alterations in the expression of cytochrome c oxidase subunits in doxorubicin-resistant leukemia K562 cells. Biochem Pharmacol 2002;63:823-831.

25. Boren J, Cascante M, Marin S, Comin-Anduix B, Centelles JJ, Lim S, Bassilian S, Ahmed S, Lee WN, Boros LG. Gleevec (STI571) influences metabolic enzyme activities and glucose carbon flow toward nucleic acid and fatty acid synthesis in myeloid tumor cells. J Biol Chem 2001;276:37747-37753.

26. Roumiantsev S, de Aos IE, Varticovisi L, Ilaria RL, VAN ETTEN RA. The src homology 2 domain of $\mathrm{Bcr} / \mathrm{Abl}$ is required for efficient induction of chronic myeloid leukemia-like disease in mice but not for lymphoid leukemogenesis or activation of phosphatidylinositol 3-kinase. Blood 2001;97:4-13.

27. Lozzio CB, Lozzio BB. Human chronic myelogenous leukemia cell-line with positive Philadelphia chromosome. Blood 1975;45:321-334.

28. Eaves AC, Cashman JD, Gaboury LA, Kalousek DK, EAVES CJ. Unregulated proliferation of primitive chronic myeloid leukemia progenitors in the presence of normal marrow adherent cells. Proc Natl Acad Sci USA 1986;83:5306-5310.

29. Andreeff M. Cell kinetics of leukemia. Semin Hematol 1986;23:300-314.

30. Kim JH, Chu SC, Gramlich JL, Pride YB, Babendreier E, Chauhan D, Salgia R, Podar K, Griffin JD, Sattler M. Activation of the PI3K/mTOR pathway by BCR-ABL contributes to increased production of reactive oxygen species. Blood 2004.

31. Skorski T, Kanakaraj P, Nieborowska-Skorska M, Ratajczak MZ, Wen SC, Zon G, Gewirtz AM, Perussia $\mathrm{B}$, Calabretta B. Phosphatidylinositol-3 kinase activity is regulated by $\mathrm{BCR} / \mathrm{ABL}$ and is required for the growth of Philadelphia chromosome-positive cells. Blood 1995;86: 726-736. 
32. Gutierrez Mi, Siraj AK, Bhargava M, Ozbek U, Banavali S, Chaudhary MA, El Solh H, Bhatia K. Concurrent methylation of multiple genes in childhood ALL: correlation with phenotype and molecular subgroup. Leukemia 2003;17:1845-1850.

33. Herrmann PC, Gillespie JW, Charboneau L, Bichsel VE, Paweletz CP, Calvert VS, Kohn EC, Emmert-Buck MR, Liotta LA, Petricoin EF 3rd. Mitochondrial proteome: altered cytochrome c oxidase subunit levels in prostate cancer. Proteomics 2003;3:1801-1810.

34. Gesbert F, Griffin JD. Bcr/Abl activates transcription of the Bcl-X gene through STAT5. Blood 2000;96:22692276.

35. Stewart MJ, Litz-Jackson S, Burgess GS, Williamson EA, Leibowitz DS, Boswell HS. Role for E2F1 in p210 BCR-ABL downstream regulation of c-myc transcription initiation. Studies in murine myeloid cells. Leukemia 1995;9:1499-1507.

36. Gustafson WC, Ray S, Jamieson L, Thompson EA, BRASIER AR, Fields AP. Bcr-Abl regulates protein kinase Ciota (PKCiota) transcription via an Elk1 site in the PKCiota promoter. J Biol Chem 2004;279:9400-9408.

37. Ghaffari S, Jagani Z, Kitidis C, Lodish HF, KhosraviFAR R. Cytokines and BCR-ABL mediate suppression of TRAIL-induced apoptosis through inhibition of forkhead FOXO3a transcription factor. Proc Natl Acad Sci USA 2003;100:6523-6528.

38. Ohmine K, Ota J, Ueda M et al. Characterization of stage progression in chronic myeloid leukemia by DNA microarray with purified hematopoietic stem cells. Oncogene 2001;20:8249-8257.

39. Hakansson P, Lassen C, Olofsson T, Baldetorp B, Karlsson A, Gullberg U, Fioretos T. Establishment and phenotypic characterization of human U937 cells with inducible $\mathrm{P} 210 \mathrm{BCR} / \mathrm{ABL}$ expression reveals upregulation of CEACAM1 (CD66a). Leukemia 2004;18:538-547.

40. Kerchner KR, Clay RL, McCleery G, Watson N, McIntire WE, Myung CS, Garrison JC. Differential sensitivity of phosphatidylinositol 3-kinase p110gamma to isoforms of $\mathrm{G}$ protein betagamma dimers. $\mathrm{J}$ Biol Chem 2004;279:44554-44562.
41. SAwyers CL. The role of myc in transformation by BCRABL. Leuk Lymphoma 1993;11(Suppl. 1):45-46.

42. Florenes VA, Faye RS, Maelandsmo GM, Nesland JM, Holm R. Levels of cyclin D1 and D3 in malignant melanoma: deregulated cyclin D3 expression is associated with poor clinical outcome in superficial melanoma. Clin Cancer Res 2000;6:3614-3620.

43. Martinez-Gac L, Marques M, Garcia Z, Campanero MR, Carrera AC. Control of cyclin G2 mRNA expression by forkhead transcription factors: novel mechanism for cell cycle control by phosphoinositide 3-kinase and forkhead. Mol Cell Biol 2004;24:2181-2189.

44. Thiele J, Zirbes TK, Lorenzen J, Kvasnicka HM, Dresbach S, Manich B, Leder LD, Niederle N, Diehl V, FISCHER R. Apoptosis and proliferation (PCNA labelling) in CML - a comparative immunohistological study on bone marrow biopsies following interferon and busulfan therapy. J Pathol 1997;181:316-322.

45. Mathupala SP, Rempel A, Pedersen PL. Aberrant glycolytic metabolism of cancer cells: a remarkable coordination of genetic, transcriptional, post-translational, and mutational events that lead to a critical role for type II hexokinase. J Bioenerg Biomembr 1997;29:339-343.

46. Munoz-Pinedo C, Ruiz-Ruiz C, Ruiz de Almodovar C, Palacios C, Lopez-Rivas A. Inhibition of glucose metabolism sensitizes tumor cells to death receptor-triggered apoptosis through enhancement of death-inducing signaling complex formation and apical procaspase- 8 processing. J Biol Chem 2003;278:12759-12768.

47. Druker BJ, Talpaz M, Resta DJ et al. Efficacy and safety of a specific inhibitor of the BCR-ABL tyrosine kinase in chronic myeloid leukemia. N Engl J Med 2001;344:10311037.

48. Druker BJ, Sawyers Cl, Kantarjian H, Resta DJ, Reese SF, Ford JM, Capdeville R, Talpaz M. Activity of a specific inhibitor of the BCR-ABL tyrosine kinase in the blast crisis of chronic myeloid leukemia and acute lymphoblastic leukemia with the Philadelphia chromosome. N Engl J Med 2001;344:1038-1042. 